\title{
Comfort and cow behavior during periods of intense precipitation
}

\author{
O.O. Borshch ${ }^{1}$, S.Yu. Ruban², B.V. Gutyj ${ }^{3 *}$, O.V. Borshch ${ }^{1}$, O.I. Sobolev', L.T. Kosior ${ }^{1}$, \\ M.M. Fedorchenko ${ }^{1}$, A.A. Kirii' ${ }^{2}$, Y. I. Pivtorak ${ }^{3}$, I. Yu. Salamakha ${ }^{4}$, N. M. Hordiichuk' ${ }^{3}$, \\ L.M. Hordiichuk ${ }^{3}$, O.I. Kamratska ${ }^{3}$, B.S. Denkovich ${ }^{3}$ \\ ${ }^{1}$ Bila Tserkva National Agrarian University, Bila Tserkva, Ukraine \\ ${ }^{2}$ National University of Life and Environmental Science of Ukraine, Kyiv, Ukraine \\ ${ }^{3}$ Stepan Gzhytskyi National University of Veterinary Medicine and Biotechnology, Lviv, Ukraine \\ ${ }^{4}$ Lviv National Agrarian University, Dubliany, Ukraine \\ *Corresponding author E-mail: bvh@ukr.net \\ Received: 13.10.2020. Accepted 24.11.2020
}

\begin{abstract}
The purpose of this work was to study the influence of prolonged precipitation as rain on the behavior and comfortable resting place of cows by housing on open feedlots with and without shelters. It was found that the duration of lying down was longer by 47 minutes for the variant of housing on open feedlots with shelters and eating feed by 8 minutes in compared to open feedlots without shelters. Concerning to the indicators of standing and motion behaviour, the duration of these behavioural act by the variant of housing on open feedlots without shelters was slightly longer compared to housing on open feedlots with shelters: by 29 and 18 minutes, respectively. The skin temperature of cows was $0.4{ }^{\circ} \mathrm{C}$ higher by housing on open feedlots without shelters than that cow by housing on open feedlots with shelters. The temperature of resting place under lying cow was also higher by housing on open feedlots without shelters (by $0.6^{\circ} \mathrm{C}$ ). At the same time, the temperature in recreation areas under the shelters prevailed by $0.2^{\circ} \mathrm{C}$, the same indicator by housing on open feedlots without shelters. The average values of daily energy consumption for basic metabolism and heat exchange were 1.50 MJ higher by housing on open feedlots without shelters. The best scores on the indices of hygienic assessment and comfort housing conditions were by the variant of housing on open feedlots with shelters. The cows were slightly less polluted on their flanks, udders and limbs by housing of this technology than by housing on open feedlots without shelters.

Key words: cows, comfort, behavior, open feedlots, atmospheric precipitation.
\end{abstract}

\section{Introduction}

Cows comfort is a management system that aims to preserve the health, increase life expectancy and productive animals use on the farm (Borshch, et al., 2019; Kulyaba et al., 2019; Grymak et al., 2020; Mazur et al., 2020).

Sufficient feed supply, water and free access to them, fresh air, soft and clean litter in recreation area, comfortable stall equipment, high quality floor, adequate lighting - these are the main components of cows comfort. Research and experience show that comfort is provided when animals in cowshed feel natural and free, as well as on the pasture lands (Hempel et al., 2019; Borshch et al., 2020a).

Housing cows on open feedlots contributes to the better physiological functioning of the animal's body and has many advantages over housing them in various types of facilities (Calegari et al., 2014; Angrecka \& Herbut, 2017). The main advantages of this housing type that animals are outdoors around the clock under the direct influence of ultraviolet rays. According to this variant of cows housing, there is an increased hormone serotonin_concentration in blood, which has a positive effect on the course of metabolic processes in the body. Housing cattle on open feedlots and pastures are most favorable for the normal functioning of hoof horn. Research by many authors has confirmed a positive correlation between the effect of housing cows on open feedlots and percentage of culling from the herd due to limb problems (Schüller et al., 2014; Borshch et al., 2020b). Cows that are housed throughout the year or seasonally on open feedlots have better reproductive traits, higher feed conversion and significantly reduced risk of respiratory diseases (Smith et al., 2016).

Open feedlots come in a variety of types, with different variants for placing feed table (on one or both sides, or all the way around), with shelters or without them, artificial lighting, such adjacent to the facilities and those that provide for grazing animals on specially organized alleys (Borshch et al, 2017a; Borshch et al., 2017b; Ruban et al., 2020). All these technological elements improve or worsen the comfort housing cows (Brown-Brandl et al., 2005; Angrecka \& Herbut 2016; Yi et al., 2018). Low temperatures combined with intense precipitation and wind have an impact on the physiological characteristics and behavior of cattle (Bergen et al., 2001; Kennedy et al., 2005). The sympathetic nervous system elicits three main physiological responses to cold stress: increased heat production metabolism, increased heart rate and mobilization of free fatty acids for 
metabolism (Broucek et al., 1991; Ruban et al., 2017). Behavioral responses during periods of intense precipitation can be divided into two categories: animals try to find a warm and comfortable place to rest in order to reduce the influence of temperature factor and change the duration of behavioural act (Houseal \& Olson, 1995; Redbo et al., 2001). Cold stress significantly affects to the animals' bodies when they are kept on pastures all year round (Kadzere et al., 2002; Mondaca et al., 2013). Low temperatures combined with wind and precipitation increase the level of cortisol hormone in cow's blood, which is a stress marker (Webster et al., 2008). Animals would seek the shelter of forests or shelters and do not willingly lie down on wet and dirty ground, which leads to loss of productivity (Schutz et al., 2010). Accordingly, the influence of these conditions leads to the fact that cows increased their metabolic activity in order to release heat to maintain their own body temperature (Ames \& Insley, 1987). As a result, the energy need for basic metabolism increases and consequently the amount of energy for other processes, such as milk production and sexual activity decreases (Broucek et al., 1991).

The purpose of this research was to study the influence of prolonged precipitation on the behavior and comfortable resting place of dairy cows by housing on open feedlots with and without shelters.

\section{Materials and Methods}

Weather. The research was conducted in the Central Forest-Steppe (Bila Tserkva district, Kyiv region) during the period of intense precipitation in the form of rain and strong wind gusts (from 19.05 to 31.05 2020). The main weather indicators for different research periods are shown in table 1.

Table 1. The main weather indicators during research period

\begin{tabular}{|c|c|c|c|c|c|}
\hline Date & Air temperature, ${ }^{\circ} \mathrm{C}$ & $\begin{array}{c}\text { Relative humidity, } \\
\%\end{array}$ & $\begin{array}{l}\text { The amount of } \\
\text { precipitation, } \mathrm{mm}\end{array}$ & Wind Speed, m/s & $\begin{array}{c}\text { Atmospheric } \\
\text { pressure, } \\
\text { mm Hg }\end{array}$ \\
\hline 19.05 & 12.3 & 83.3 & 7.9 & 2.5 & 749 \\
\hline 20.05 & 13.6 & 77.8 & 6.2 & 5.0 & 744 \\
\hline 21.05 & 10.4 & 65.4 & 5.1 & 4.2 & 746 \\
\hline 22.05 & 8.5 & 63.2 & 4.5 & 5.1 & 746 \\
\hline 23.05 & 9.7 & 70.6 & 5.0 & 4.4 & 749 \\
\hline 24.05 & 10.5 & 72.7 & 5.3 & 2.0 & 750 \\
\hline 25.05 & 10.4 & 83.0 & 7.7 & 2.6 & 750 \\
\hline 26.05 & 11.9 & 88.4 & 8.5 & 3.4 & 751 \\
\hline 27.05 & 13.1 & 78.2 & 6.6 & 2.8 & 752 \\
\hline 28.05 & 12.7 & 80.3 & 7.1 & 4.4 & 748 \\
\hline 29.05 & 14.0 & 74.5 & 5.8 & 2.2 & 741 \\
\hline 30.05 & 14.2 & 93.4 & 9.4 & 3.4 & 737 \\
\hline 31.05 & 14.8 & 78.2 & 6.5 & 3.4 & 738 \\
\hline $\begin{array}{c}\text { average } \\
\text { data }\end{array}$ & 12.1 & 77.6 & 6.7 & 3.5 & 746.2 \\
\hline
\end{tabular}

Cows. We used Ukrainian black and speckled cow's breed of 1-3 lactation increasing the milk yield (50 to 120 day of lactation). Types of housing cows. The research was conducted in two farms by the variants of housing cows on open feedlots with and without shelters.

Comfort techniques. The comfort conditions of housing livestock were determined by a complex score, which consisted of the following indicators: daily behavior of cows, animals' contamination, limbs and udders injuries. The presence of unsatisfactory indicators (daily behavior does not correspond to established standards, frequent lameness in herd, too contaminated limbs or udders) were considered as zero comfort - 0 points, satisfactory indicators (partially contaminated limbs or udders) were 0.5 points and the absence of unsatisfactory indicators were 1 point. The highest amount of points indicates comfort and advantage of housing technology.

The hygiene assessment was performed by 3-point Cook', (2007) scale. Cows whose udder, limbs and flanks were not dirt put 1 point and for cows with a small contamination of limbs (or flanks) put 2 points and for cows with contaminated parts of the body put 3 points.

Behaviour. Cow' behavior was determined by using indoor security cameras. 12 IP cameras (2 MG) are installed by T-1variant of housing cow; 8 Hikvision cameras (Full HD) by open feedlot with shelters and 12 Hikvision cameras (Full HD) by open feedlot without shelters. Shooting in all storerooms takes place around the clock. In sheds, rest area and manger space recorded by camera.The daily cows' behavior was recording for two consecutive days around the clock during intense precipitation period. Every 10 minutes in the experimental groups recorded the number of cows that eating, lying down and standing during the observation.

Thermal conditions. The average daily precipitation was determined by the Kyiv Center for Hydrometeorology. The cows skin surface temperature was determined in two places: on rumen and in the region of the last inter costal space by using a remote infrared thermometer Thermo Spot Plus (Germany). The temperature at the resting place as well as under the lying cow was determined by the thermometer A36PF-D43 (USA). Costs of energy for heat production were calculated according to the methods of Kadzere et al. (2002). 
Statistical analysis. The obtained data were statistically processed using STATISTICA (Version 11.0, 2012) software. The Student's $t$-test was used to estimate the statistical significance of the obtained values. Data were considered significant at $\mathrm{P}<0.05, \mathrm{P}<$ $0.01, P<0.001$.

\section{Results and Discussion}

Research have shown that duration of the main behavioural acts of cows during intense precipitation and strong wind gusts differed depending by type of housing (table 2). Thus, the indicators of the duration of lying down and eating feed in the case of housing on open feedlots with shelters, which are the main ones in determining the comfort of housing, were longer by 47 minutes and 8 minutes compared to open feedlots without shelters. Concerning to the indicators of standing and motion behaviour, the duration of these behavioural acts by variant of housing on open feedlots without shelters was slightly longer compared to housing on open feedlots with shelters: by 29 and 18 minutes, respectively.

Table 2. Duration of basic daily behavioral responses.

\begin{tabular}{|c|c|c|}
\hline Behavioural act & $\begin{array}{c}\text { Open feedlot with } \\
\text { shelters } \\
(n=76)\end{array}$ & $\begin{array}{c}\text { Open feedlot } \\
\text { without shelters } \\
(n=82)\end{array}$ \\
\hline Lying down & $728 \pm 9.16$ & $681 \pm 7.54^{\star \star \star}$ \\
\hline Standing & $209 \pm 4.57$ & $238 \pm 4.21^{* * *}$ \\
\hline Eating feed & $292 \pm 3.39$ & $284 \pm 2.15^{*}$ \\
\hline Motion behaviour & $74 \pm 0.82$ & $92 \pm 1.07^{* * *}$ \\
\hline
\end{tabular}

Note: as compared with feedlot with shelters

The results of our research do not coincide by Schütz et al., 2010, in which indicated a reduction in the duration of cows lying time under shelters during periodic simulation of rain and wind.

Parameters of cow behavior can be used by farm workers as a signal about their health, comfort housing and well-being. They show the advantages or disadvantages of feeding, housing and reproduction processes. Knowledge of the daily main acts duration of cows' behavior by various housing technologies are indicators that helps and improves the processes of herd management. Our research have shown that the indicators of the number of cows that eat feed immediately after it is distributed, or milking, and the number of cows that rested and chewed cud of 1.5 hours after feed distribution by 2.35 and $1.22 \%$ prevailed by housing on open feedlots with shelters (table 3 ). The data obtained indicate slightly higher ethological indicators of cow comfort by this variant of extensive housing.

Table 3. Ethological indicators that characterize the comfort housing

\begin{tabular}{lcc}
\multicolumn{1}{c}{ Indicators } & $\begin{array}{c}\text { Open feedlot with shelters } \\
(\mathrm{n}=76)\end{array}$ & $\begin{array}{c}\text { Open feedlot } \\
\text { without shelters }(\mathrm{n}=82)\end{array}$ \\
\hline $\begin{array}{l}\text { The number of cows that eat feed immediately after it is } \\
\text { distributed or milked, \% from size of the group }\end{array}$ & $82.56 \pm 0.87$ & $80.21 \pm 0.74^{*}$ \\
$\begin{array}{l}\text { The number of cows that rest and chew a cud of 1.5 hours } \\
\text { after feed distribution, \% from size of the group }\end{array}$ & $85.39 \pm 1.44$ & $84.17 \pm 1.29$ \\
\hline
\end{tabular}

Note: as compared with feedlot with shelters

Indicators of skin temperature, resting places and resting places under a lying cow are important because they affect on energy consumption of animals (Kadzere et al., 2002). In our research, the skin temperature of cows was $0.4{ }^{\circ} \mathrm{C}$ higher by housing on open feedlots without shelters than that of cows by housing on open feedlots with shelters (table 4). The temperature of resting place under lying cow was also higher by housing on open feedlots without shelters (by $0.6{ }^{\circ} \mathrm{C}$ ). At the same time, the temperature in recreation areas under the shelters prevailed by $0.2{ }^{\circ} \mathrm{C}$, the same indicator was by housing on open feedlots without shelters. The average values of daily energy consumption for basic metabolism and heat exchange were $1.50 \mathrm{MJ}$ higher by housing on open feedlots without shelters.

Table 4. The temperature indicators of resting place and energy consumption for heat production

\begin{tabular}{lcc}
\multicolumn{1}{c}{ Indicators } & $\begin{array}{c}\text { Open feedlot with shelters } \\
(\mathrm{n}=25)\end{array}$ & $\begin{array}{c}\text { Open feedlot } \\
\text { without shelters }(\mathrm{n}=25)\end{array}$ \\
\hline $\begin{array}{l}\text { Skin temperature, }{ }^{\circ} \mathrm{C} \\
\text { Temperature in resting place, }{ }^{\circ} \mathrm{C}\end{array}$ & $33.3 \pm 0.08$ & $33.7 \pm 0.008^{* *}$ \\
Temperature in resting place under lying cow, ${ }^{\circ} \mathrm{C}$ & $12.8 \pm 0.06$ & $12.6 \pm 0.005^{* *}$ \\
& $27.2 \pm 0.23$ & $27.8 \pm 0.15^{*}$ \\
Daily energy costs for basic metabolism and heat & $44.7 \pm 0.51$ & $46.2 \pm 0.54^{*}$ \\
\hline
\end{tabular}

Note: as compared with feedlot with shelters 
We used comfort index for a more detailed assessment of cows housing on open feedlots (table 5). The best scores for all indices were by variant of housing on open feedlots with shelters. The cows were slightly less polluted on their flanks, udders and limbs by this technology of housing than by housing on open feedlots without shelters.

Table 5. Indices that characterize comfort of housing cows

\begin{tabular}{lcc}
\multicolumn{1}{c}{ Indicators } & Open feedlot with shelters $(\mathrm{n}=76)$ & $\begin{array}{c}\text { Open feedlot } \\
\text { without shelters }(\mathrm{n}=82)\end{array}$ \\
\hline Index of comfort conditions housing & $3.28 \pm 0.04$ & $3.06 \pm 0.003^{* * *}$ \\
Index of hygienic assessment, point & $1.52 \pm 0.01$ & $1.75 \pm 0.002^{* \star *}$ \\
\hline
\end{tabular}

Note: as compared with feedlot with shelters

\section{Conclusions}

It has established that shelters on open feedlots during precipitation period as rain had a positive impact on ethological indicators of comfortable housing conditions in comparison by housing on open feedlots without shelters. In addition, lower daily energy costs for basic metabolism and heat production were observed by this housing system, as well as better average values of the indices of hygienic assessment and comfortable housing conditions.

\section{References}

Ames, D.R., \& Insley, L.W. (1975). Wind-chill effect for cattle and sheep. Journal of Animal Science, 40, $161-165$. https://doi.org/10.2527/jas1975.401161x

Angrecka, S., \& Herbut, P. (2016). Impact of Barn Orientation on Insolation and Temperature of Stalls Surface. Annals of Animal Science, 16 (3), 887-896. doi: 10.1515/aoas-2015-0096

Angrecka, S., \& Herbut, P. (2017). Eligibility of lying boxes at different THI levels in a freestall barn. Annals of Animal Science, 17, 257-269. https://doi.org/10.1515/aoas-2016-0053

Bergen, R.D., Kennedy, A.D., \& Christopherson, R.J. (2001). Effects of intermittent cold exposure varying in intensity on core body temperature and resting heat production of beef cattle. Canadian Journal of Animal Science, 81, 459-465.

Borshch, A.A., Ruban, S., Borshch, A.V., \& Babenko, O.I. (2019). Effect of three bedding materials on the microclimate conditions, cows behavior and milk yield. Polish Journal of Natural Sciences, 34 (1), 19-31.

Borshch, O.O., Borshch O.V., Kosior L.T., Pirova, L.V., \& Lastovska, I.O. (2017a). Influence of various litter materials and premises characteristics on the comfort and behavior of cows. Journal of Ecology, 7 (4), 529-535. doi: 10.15421/2017_156

Borshch, O.O., Borshch, O.V., Donchenko, T.A., Kosior, L.T., \& Pirova, L.V. (2017b). Influence of low temperatures on behavior, productivity and bioenergy parameters of dairy cows kept in cubicle stalls and deep litter system. Ukrainian Journal of Ecology, 7 (3), 73-77. doi: 10.15421/2017_51

Borshch, O.O., Gutyj, B.V., Borshch, O.V., Sobolev, O.I., Chernyuk, S.V., Rudenko, O.P., Kalyn, B.M., Lytvyn, N.A., Savchuk, L.B., Kit, L.P., Nahirniak, T.B., Kropyvka, S.I., \& Pundyak, T.O. (2020b). Environmental pollution caused by the manure storage. Ukrainian Journal of Ecology, 10 (3), 110-114. doi: 10.15421/2020_142

Borshch, O.O., Gutyj, B.V., Sobolev, O.I., Borshch, O.V., Ruban, S.Yu., Bilkevich, V.V., Dutka, V.R., Chernenko, O. M., Zhelavskyi, M. M., \& Nahirniak, T. (2020a). Adaptation strategy of different cow genotypes to the voluntary milking system. Ukrainian Journal of Ecology, 10 (1), 145-150. doi: 10.15421/2020_23.

Broucek, J., Letkovicova, M., \& Kovalcuj, K. (1991). Estimation of cold stress effect on dairy cows. International Journal of Biometeorology, 35, 29-32. doi: 10.1007/BF01040960

Brown-Brandl, T.M., Eigenberg, R.A., Nienaber, J.A., \& Hahn, J.L. (2005). Dynamic response indicators of heat stress in shaded and non-shaded feedlot cattle, part 1: analysis of indicators. Biosystems Engineering, 91(4), 451-462. doi:10.1016/j.biosystemseng.2004.12.006

Calegari, F., Calamari, L., \& Frazzi, E. (2014). Fan cooling of the resting area in a free stalls dairy barn. International Journal of Biometeorology, 58, 1225-1236. doi: 10.1007/s00484-013-0716-1

Cook, N.B. (2007). The Dual Roles of Cow Comfort in the 'Get Lame - Stay Lame' Hypothesis. Sixth International Dairy Housing Conference Proceeding 16-18 June 2007, (Minneapolis, Minnesota, USA) Publication Date 16 June 2007. ASABE Publication Number 701P0507e (doi:10.13031/2013.22819)

Grymak, Y., Skoromna, O., Stadnytska, O., Sobolev, O., Gutyj, B., Shalovylo, S., Hachak, Y., Grabovska, O., Bushueva, I., Denys, G., Hudyma, V., Pakholkiv, N., Jarochovich, I., Nahirniak, T., Pavliv, O., Farionik, T., \& Bratyuk, V. (2020). Influence of "Thireomagnile" and "Thyrioton" preparations on the antioxidant status of pregnant cows. Ukrainian Journal of Ecology, 10(1), 122-126. doi: 10.15421/2020_19

Hempel, S., Menz, C., Pinto, S., Galán, E., Janke, D., Estellés, F., Müschner-Siemens, T., Wang, X., Heinicke, J., Zhang, G., Amon, B., Del Prado, A., \& Amon, T. (2019). Heat stress risk in European dairy cattle husbandry under different climate change scenarios - uncertainties and potential impacts. Earth System Dynamics, 10, 859-884. https://doi.org/10.5194/esd-10859-2019

Houseal, G.A., \& Olson, B.E. (1995). Cattle use of microclimates on a northern latitude winter range. Canadian Journal of Animal Science, 75, 501-507.

Kadzere, C.T., Murphy, M.R., Silanikove, N., \& Maltz, E. (2002). Heat stress in lactating dairy cows: a review. Livestock Production Science, 77, 59-91. doi: 10.1016/S0301-6226(01)00330-X 
Kennedy, A.D., Bergen, R.D., Christopherson, R.J., Glover, N.D., \& Small J.A. (2005). Effect of once daily 5-h or 10-h cold-exposures on body temperature and resting heat production of beef cattle. Canadian Journal of Animal Science, 85, 177-183.

Kulyaba, O., Stybel, V., Gutyj, B., Turko, I., Peleno, R., Turko, Ya., Golovach, P., Vishchur, V., Prijma, O., Mazur, I., Dutka, V., Todoriuk, V., Golub, O. Dmytriv, O., \& Oseredchuk, R. (2019). Effect of experimental fascioliasis on the protein synthesis function of cow liver. Ukrainian Journal of Ecology, 9(4), 612-615

Mazur, N.P., Fedorovych, V.V., Fedorovych, E.I., Fedorovych, O.V., Bodnar, P.V., Gutyj, B.V., Kuziv, M.I., Kuziv, N.M., Orikhivskyi, T.V., Grabovska, O.S., Denys, H.H., Stakhiv, N.P., Hudyma, V.Yu., \& Pakholkiv, N.I. (2020). Effect of morphological and biochemical blood composition on milk yield in Simmental breed cows of different production types. Ukrainian Journal of Ecology, 10(2), 61-67.doi: 10.15421/2020_110

Mondaca, M., Rojano, F., Choi, C.Y., \& Gebremedhin, K.G. (2013). A conjugate heat and mass transfer model to evaluate the efficiency of conductive cooling for dairy cattle. Transactions of the ASABE, 56, 1471-1482. doi: 10.13031/trans.56.10178

Redbo, I., Ehrlemark, A., \& Redbo-Torstensson, P. (2001). Behavioural responses to climatic demands of dairy heifers housed outdoors. Canadian Journal of Animal Science, 81, 9-15.

Ruban, S., Borshch, O.O., Borshch, O.V., Orischuk, O., Balatskiy, Y., Fedorchenko, M., Kachan, A., \& Zlochevskiy, M. (2020). The impact of high temperatures on respiration rate, breathing condition and productivity of dairy cows in different production systems. Animal Science Papers and Reports, 38 (I), 61-72.

Ruban, S.Yu., Borshch, O.V., \& Borshch, O.O. (2017). Suchasni tekhnolohiyi vyrobnytstva moloka. (osoblyvosti ekspluatatsiyi, tekhnolohichni rishennya, eskizni proekty) [Modern milk production technologies. (peculiarities of operation, technological decisions, sketch designs)]. Kharkiv: STYLIZDAT (in Ukrainian)

Schüller, K.L., Burfeind, O., \& Heuwieser, W. (2014). Impact of heat stress on conception rate of dairy cows in the moderate climate considering different temperature-humidity index thresholds, periods relative to breeding, and heat load indices. Theriogenology, 81 (8), 1050-1057. doi: 10.1016/j.theriogenology.2014.01.029.

Schutz, K.E., Clark, K.V., Cox, N.R., Matthews, L.R., \& Tucker, C.B. (2010). Responses to short-term exposure to simulated rain and wind by dairy cattle: time budgets, shelter use, body temperature and feed intake. Animal Welfare, 19, 375-383.

Smith, J.F., Bradford, B.J., Harner, J.P., Potts, J.C., Allen, J.D., Overton, M.W., Ortiz, X.A., \& Collier, R.J. (2016). Short communication: Effect of cross ventilation with orwithout evaporative pads on core body temperature and resting time of lactating cows. Journal of Dairy Science, 99, 1495-1500. doi: 10.3168/jds.2015-9624

Webster, J.R., Stewart, M., Rogers, A.R., \& Verkerk, G.A. (2008). Assessment of welfare from physiological and behavioural responses of New Zealand dairy cows exposed to cold and wet conditions. Animal Welfare, 17, 19-26.

Yi, Q., König, M., Janke, D., Hempel, S., Zhang, G., Amon, B., \& Amon, T. (2018). Wind tunnel investigations of sidewall opening effects on indoor airflows of a cross-ventilated dairy building. Energy and Buildings, 175, $163-172$. https://doi.org/10.1016/j.enbuild.2018.07.026

\section{Citation:}

Borshch, O.O., Ruban, S.Yu., Gutyj, B.V., Borshch, O.V., Sobolev, O.I., Kosior, L.T., Fedorchenko, M.M., Kirii, A.A., Pivtorak, Y.I., Salamakha, I.Yu., Hordiichuk, N.M., Hordiichuk, L.M., Kamratska, O.I., Denkovich, B.S. (2020). Comfort and cow behavior during periods of intense precipitation. Ukrainian Journal of Ecology, 106), 98-102.

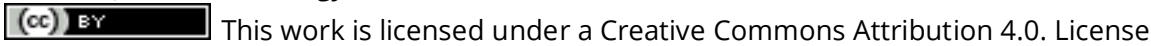

